BLS 33, No 1 2007. DOI: http://dx.doi.org/10.3765/bls.v33i1.3525

(published by the Berkeley Linguistics Society and the Linguistic Society of America)

\title{
Object Case and Event Type: Accusative-Dative Object Case Alternation in Japanese*
}

\author{
SHIN FUKUDA \\ University of California, San Diego
}

\section{Introduction}

A small group of Japanese verbs allows for their object to be case marked with either accusative $-o$ or dative $-n i$ (Kuno 1973).
(1) a. Gakusei-ga yama-o/ni
nobor -ta
student-NOM mountain-ACC/DAT
climb - PERF $^{1}$
'Students climbed the mountain.'
b. Kodomo-ga kabin-o/ni sawar -ta children-NOM vase-ACC/DAT touch -PERF 'The children touched the vase.'

I refer this alternation as Acc-Dat alternation, and the verbs that participate in the alternation as the alternating verbs. As originally noted in Kuno (1973) and also in Sugamoto (1982), the Acc-Dat alternation is accompanied by contrasts in the interpretation of the arguments and the event type of the sentences. First, with the alternating verbs, an accusative object is interpreted as a path argument, while a dative object is interpreted as a goal argument (Kuno 1973). Second, the alternating verbs with an accusative object denote durative events, whereas the same verbs with dative object denote instantaneous events (Sugamoto 1982).

\footnotetext{
* Many thanks are due to Ivano Caponigro, John Moore, and the audience at BLS 33 for their suggestions and comments for this paper. The usual disclaimers apply.

1 Abbreviations: $\mathrm{ACC}=$ accusative, $\mathrm{BY}=$ by-phrase, $\mathrm{CL}=$ classifier, $\mathrm{DAT}=$ dative, $\mathrm{IMPERF}=$ imperfect, $\mathrm{LOC}=$ locative, $\mathrm{NOM}=$ nominative, $\mathrm{PERF}=$ perfective, $\mathrm{PL}=$ plural

${ }^{2}$ Following Sadakane and Koizumi (1995), I take the fact that $-n i$ in (1a) and (1b) can host a stranded numeral quantifier as an indication that it is dative case, not a postposition.
}

$\begin{array}{lllll}\text { Gakusei-ga } & \text { yama }_{\mathrm{i}} \text {-ni } & \text { 2-tsu } & \text { nobor } & \text {-ta } \\ \text { student-NOM } & \text { mountain }_{\mathrm{i}} \text {-DAT } & \text { 2-CL } & \text { climb } & \text {-PERF }\end{array}$


Shin Fukuda

Third, as argued in this paper, subjects are interpreted as agent and theme with an accusative and a dative object, respectively. In this paper, I first present evidence from three language-specific diagnostics for unaccusativity that the Acc-Dat alternation is a case of unergative/unaccusative alternation, where the core argument of a verb is realized as either the external (unergative) or internal (unaccusative) argument. I then propose a syntactic analysis of the Acc-Dat alternation, according to which the alternating verbs are mapped into two different syntactic structures which determine (i) how the arguments of the verbs are interpreted (ii) how they are case-licensed, and (iii) the aspectual specification of resulting sentences. I also argue that the proposed analysis accounts for behavior of a group of Japanese verbs whose internal argument must be marked with dative case, providing an independent motivation for the proposed analysis.

\section{Three Contrasts that Accompany the Acc-Dat Alternation \\ 1.1. Interpretation of Objects: Path vs. Goal}

According to Kuno (1973), when a verb allows for the Acc-Dat alternation, accusative case indicates that 'the motion designated by the verb takes place covering entire dimension of the NP', while dative case indicates that 'the NP is the goal of the motion designated by the goal' (Kuno 1973: 97). He convincingly shows this contrast by using objects that strongly favors one of the readings due to our pragmatic knowledge. Objects which can only be natural as path, such as kaidan 'stairs', are compatible only with accusative case (2a), whereas objects which can only be natural as goal, such as yane 'roof', are compatible only with dative case (2b).
(2) a.
Gakusei-ga kaidan-o/ $/{ }^{\# \mathbf{n i}}$
student- NOM
stairs- ACC/ ${ }^{\#}$ DAT
'Students climbed the stairs.'
b. Gakusei-ga yane- ${ }^{\#}$ o/ni student- NOM roof- ${ }^{\#}$ ACC/DAT 'Students climbed to the roof.'

$$
\begin{aligned}
& \text { nobor }- \text { ta } \\
& \text { climb - PERF }
\end{aligned}
$$
nobor -ta
climb - PERF

1.2. Interpretation of Event Type: Durative vs. Instantaneous

Another contrast accompanying the Acc-Dat alternation is that of event type. A sentence with an alternating verb has a durative interpretation with an accusative marked object, while it has an instantaneous interpretation with a dative marked object. Evidence for this claim can be found in Sugamoto (1982), who shows that the alternating verbs are compatible with completive aspect verbs, such as kir 'complete', only with an accusative marked object.

$$
\begin{array}{llll}
\text { Gakusei-ga } & \text { yama-o/ } / \# \text { ni } & \text { nobori kir } & \text {-ta } \\
\text { student-NOM mountain-ACC/ }{ }^{\#} \text { DAT } & \text { climb complete } & \text {-PERF } \\
\text { 'Students finished climbing the mountain.' } & &
\end{array}
$$




\section{Accusative-Dative Case Alternation in Japanese}

Likewise, adverbials that imply a durative interpretation are only compatible with an accusative marked object, as in (4).

$$
\begin{array}{lllll}
\text { Kodomo-tachi-ga } & \text { [te-ni-motte }] & \text { kabin-o/ }{ }^{\# n} & \text { sawar } & \text {-ta } \\
\text { child-PL- NOM } & \text { [hand-LOC-have } & \text { vase-ACC/ } /^{\#} \text { DATtouch } & \text {-PERF } \\
\text { 'The children touched the vase while holding it.' }
\end{array}
$$

Since both completing an event and an action of holding an object necessarily imply duration, the dative marked object, which forces an instantaneous interpretation of events, is infelicitous in (3) and (4).

\subsection{Interpretation of Subjects: Agent vs. Theme}

The third and previously unnoticed contrast with the Acc-Dat alternation involves a change in interpretation of subjects between agent and theme. The contrast can be seen by manipulating the animacy of the subject. As can be seen in (5) below, inanimate subjects can only be natural with an dative marked object, suggesting that an accusative marked object forces the subject to be interpreted as agent.

$\begin{array}{llll}\text { Sukaato-ga } & \text { yuka- }{ }^{\#} \text { o/ni } & \text { sawar } & \text {-ta } \\ \text { Skirt- NOM } & \text { floor- }{ }^{*} \text { ACC/DAT } & \text { touch } & \text {-PERF } \\ \text { 'The skirt touched the floor.' } & \end{array}$

Even when the subject is animate, the contrast can be seen with adverbials that are sensitive to volitionality. Non-volitional adverbials are natural only with a dative marked object.

$$
\begin{aligned}
& \text { Kodomo-ga atsui-yakan-" } \mathbf{0} \text { /ni ukkari sawar -ta } \\
& \text { child-NOM hot- kettle- }{ }^{\#} \text { ACC/DAT by.mistake touch -PERF } \\
& \text { 'The child touched the hot kettle accidentally.' }
\end{aligned}
$$

\subsection{Summary of the Alternations}

The three contrasts with the Acc-Dat alternation are summarized in the table 1.

(7) Table 1: Three contrasts accompanying the Acc-Dat alternation

\begin{tabular}{lccc}
\hline & object's role & event type & subject's role \\
\hline \hline Accusative case & path & durative & agent \\
\hline \hline Dative case & goal & instantaneous & theme \\
\hline \hline
\end{tabular}

\section{The Acc-Dat Alternation is an Unergative/unaccusative Alternation}

In this section, I argue that the Acc-Dat alternation is a case of an unergative/unaccusative alternation, a phenomenon previously described in languages such as Dutch (Perlmutter 1978, Hoekstra and Mulder 1990), English (Leven and Rappaport Hovav 1989, 1995), German (Grewendorf 1989), Italian 
Shin Fukuda

(Rosen 1984), Hebrew (Borer 1994), Caucasian (Dixon 1994), Mayan (Zavala 2007), and also Japanese (Tsujimura 1994). The evidence comes from three language-specific diagnostics for unaccusativity: (i) interpretation of takusan 'a lot', (ii) interpretation of te-iru construction, and (iii) distribution of stranded numeral quantifiers.

\subsection{Interpretation of takusan 'a lot' (Kageyama 1993)}

The first diagnostic test involves a modifier takusan 'a lot', adopted from Kageyama (1993). Kageyama argues that interpretation of takusan 'a lot' can be used to differentiate uuaccusative and unergative verbs. With unergative verbs, takusan can only modify the activities that these verbs denote (8a). With many unaccusative verbs, however, it can modify the quantity of the arguments as well as the activities that they denote (8b).
a.
Kodomo-ga takusan
child-NOM lot
aruk/asob $\quad$-ta
walk/play - PERF
'The child(ren) walked/played a lot.'(amount of the activities)
'\#Many children walked/played.'(quantity of the argument)
b. Gakusei-ga takusan toshokan-ni ik -ta student-NOM lot library go -PERF
'The student(s) went to the library a lot.'(amount of the activities)
'Many students went to the library.'(quantity of the argument)

Kageyama suggests that this contrast can be accounted for by analyzing takusan 'a lot' as a VP modifier. With unergative verbs, the subjects are external arguments by definition. Thus, takusan can only modify the verbs, resulting in the amount of activities reading. With the unaccusative verbs, on the other hand, takusan can modify either the subjects, which are assume to be base-generated as internal arguments, or the verbs themselves, allowing for both readings. Interestingly, the interpretation of takusan 'a lot' changes with the case marking on the object of the alternating verbs. It can only modify the amount of the activity with an accusative object (9a), while it is ambiguous between the quantity of the subject and the amount of the activity reading with a dative object (9b).
a. Gakusei-ga yama-o takusan nobor -ta
student-NOM mountain-ACC lot climb -PERF
'The student(s) climbed mountains a lot.' (amount of climbing)
'\#Many students climbed the mountain(s).'(quantity of the students)
b. Gakusei-ga yama-ni takusan nobor -ta student- NOM mountain-DAT lot climb -PERF
'Many students climbed mountains.'(quantity of the students)
'The student(s) climbed the mountains a lot.'(amount of climbing) 


\section{Accusative-Dative Case Alternation in Japanese}

Thus, interpretation of takusan as a diagnostic test for unaccusativity suggests that the Acc-Dat alternation is a case of an unergative/unaccusative alternation.

\subsection{Te-iru Construction (Kindaichi 1976, Jacobson 1997 among others)}

Te-iru construction is roughly the Japanese equivalent of the English progressive, as it provides an on-going interpretation of verbs denoting activities, as in (10).

$$
\begin{array}{lllll}
\text { Kodomo-ga } & \text { aruk/asob } & \text {-te } & -\mathrm{i} & \text {-ru } \\
\text { child-NOM } & \text { walk/play } & -\mathrm{TE} & -\mathrm{I} & \text {-IMPERF } \\
\text { 'The child(ren) are walking/playing.' (progressive) }
\end{array}
$$

However, te-iru construction can also create a perfective reading, with verbs that denote instantaneous events, such as umare 'be born' and $i k$ 'go'.

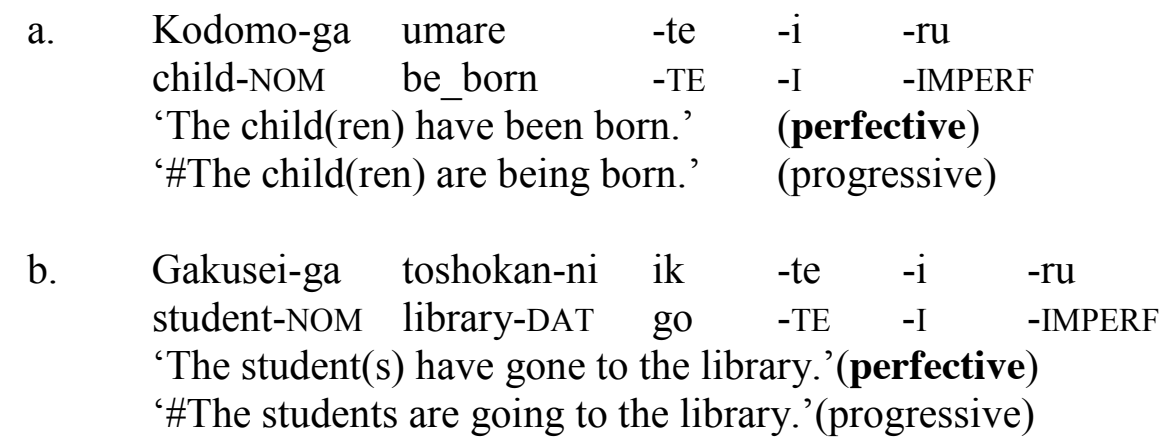

As pointed out in Jacobson (1997), when te-iru construction attaches to the alternating verbs, it creates a progressive interpretation with an accusative object and a perfective reading with a dative object.

$\begin{array}{llllll}\text { Gakusei-ga } & \text { yama-o/ni } & \text { nobor } & \text {-te } & \text {-i } & \text {-ru } \\ \text { student-NOM } & \text { mountain-ACC/DAT } & \text { climb } & -\mathrm{TE} & \text {-I } & \text { - IMPERF }\end{array}$

Accusative object $=$ 'The students are climbing the mountain.'(progressive) Dative object $=$ 'The students are on the top of the mountain.' (perfective)

Given the well-known generalization that unaccusative verbs tend to denote telic events whereas unergative verbs tend to denote atelic events (van Valin 1990, Tenny 1994, Levin and Rappaport Hovav 1995), te-iru construction can be an indirect diagnostic test for unaccusativity. Under such an assumption, the fact that te-iru construction creates either a progressive or perfective interpretation depending on the object case marking further supports the hypothesis that the Acc-Dat alternation is an unergative/unaccusative alternation.

\subsection{Stranded Numeral Quantifier Phrases (Miyagawa 1989)}

Since Miyagawa (1989), stranded numeral quantifier phrases (NQPs) have been used as a diagnostic test for unaccusativity in Japanese. Subjects of presumed 


\section{Shin Fukuda}

unaccusative verbs can license a NQP stranded in the preverbal position (13a), while subjects of presumed unergative verbs cannot (13b).
a. Gakusei -ga $_{\text {-ghisu-ni }}$
5-nin ki $_{\text {i }} \quad$-ta
student $\mathrm{i}_{\mathrm{i}}$-NOM office-LOC
5-CL $\mathbf{C}_{\mathbf{i}}$ come -PERF
'Students, five of them, came to the office.'
b. ${ }^{*}$ Gakusei $_{i}$-ga geragerato
student $_{\mathbf{i}}$-NOM loudly
5-nin i $_{\mathbf{i}}$ waraw -ta
5- $\mathbf{C L}_{\mathbf{i}}$ laugh -PERF
'Students, five of them, laughed loudly.'

Miyagawa accounts for the contrast in (13) by assuming that an NQP and the licensing NP must c-command each other at their base-generated positions. According to this analysis, the subject of an unaccusative verb can license an NQP stranded in the preverbal position because it is based-generated at the internal argument position, where it forms a constituent with the NQP (14a). The subject of an unergative verb, on the other hand, cannot license a stranded NQP, because it is an external argument and never c-commanded by the NQP (14b).

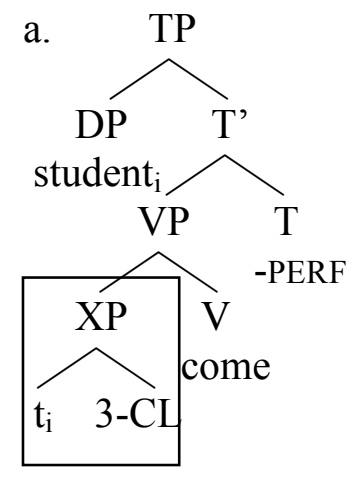

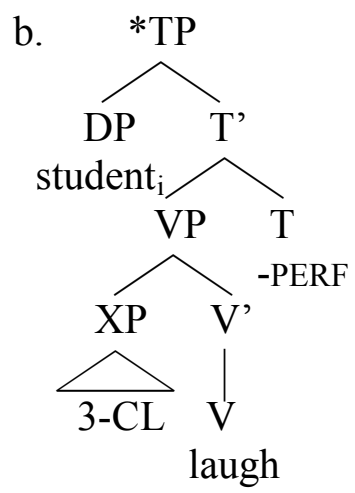

With the alternating verbs, a NQP following the object can be associated with the subject only if the object is marked with dative case.

$$
\begin{aligned}
& \text { Gakusei }_{\text {-ga }} \text { yama-*o/ni 5-nin }{ }_{\text {i }} \text { nobor -ta } \\
& \text { student } \mathrm{i}_{\mathrm{i}} \text {-NOM mountain-*ACC/ DAT 5-CL } \mathrm{C}_{\mathrm{i}} \text { climb -PERF } \\
& \text { 'Students, five of them, climbed the mountain.' }
\end{aligned}
$$

This contrast can be accounted for under the proposal that Acc-Dat alternation is an unergative/unaccusative alternation. When an object is dative marked, the alternating verbs are unaccusative. Thus, the subject originates in the internal argument position, where it licenses the preverbal NQP. 


\section{Accusative-Dative Case Alternation in Japanese}

\subsection{Summary}

In this section, I have argued that the Acc-Dat alternation is a case of unergative/unaccusative alternation, based on three language specific diagnostic tests for unaccusativity. Although the unergative/unaccusative alternation has been attested in different languages including Japanese, what is unique to the case under discussion is that the alternation manifests as different object case marking.

\section{Proposal: Deriving the Alternation in Syntax}

In this section, I present a syntactic analysis of the Acc-Dat alternation. According to the proposed analysis, lexical entries of the alternating verbs only specify what arguments these verbs require. Crucially, they do not specify how these arguments are realized in syntax (cf. Borer 1994). Instead, the alternating verbs are mapped into two distinct syntactic structures which determines (i) how the arguments are interpreted, (ii) how the arguments are case-licensed, and (iii) the aspectual specification of a given sentence.

\subsection{Unaccusative}

With an unaccusative instance of the alternating verbs, the subject is derived, as it is base-generated as an internal argument, and it is interpreted as theme. Also, the distribution of stranded NQPs suggests that the goal argument, which has dative case, is base-generated in a position higher than that of the base-generated position of the derived subject. In the proposed analysis, these observations are accounted for in the following way. First, the theme argument is generated as the internal argument, while the goal argument is generated as the specifier of VP. This VP is embedded under a functional head $v$, which case-licenses the goal argument. Thus, a sentence with the unaccusative instance of an alternating verb nobor 'climb' (17a) has the structure in (17b).

a.

$$
\begin{aligned}
& \text { Gakusei }_{i} \text {-ga yama-ni } t_{i} \text { nobor }-t a \\
& \text { student } \mathrm{t}_{\mathrm{i}} \text {-NOM mountain-DAT } \mathrm{t}_{\mathrm{i}} \text { climb -PERF } \\
& \text { 'Students climbed the mountain(s).' }
\end{aligned}
$$

b.

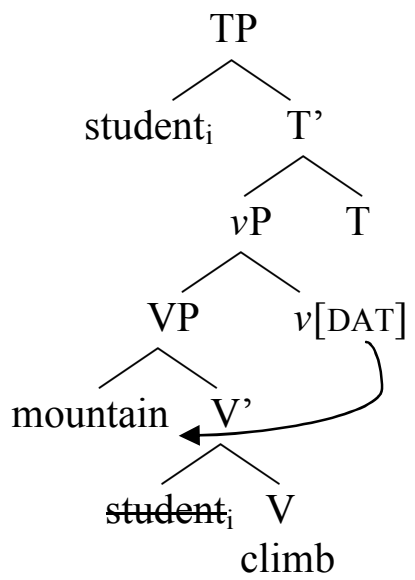




\section{Shin Fukuda}

Since the $v$ case-licenses only the goal argument, the theme argument would be case-less if it remains in situ. This forces it to move to [Spec, TP], accounting for the observation that the subject is derived with a dative marked object.

\subsection{Unergative}

In the unergative case, the alternating verbs have agentive subjects and their object is accusative marked. One way to account for the observation that the presence of agent often corresponds to the presence of accusative case, known as Burzio's generalization, has been to assume that the $v$ that introduces an agent also introduces accusative case (Krazter 1994, 1996, Chomsky 1995). Assuming that this particular $v$ is present in the unergative structure accounts for the fact that the subject is agent when the object is accusative marked. As for the difference in event types, I propose that the unergative structure involves another functional projection found between $v$ and VP, called aspect phrase (Travis 1991), which adds duration to an event. Under this analysis, the difference in the event type between unaccusative and unergative instances of the alternating verbs is due to the presence or absence of aspect phrase. The unergative instances of the alternating verbs denote durative events, since their syntax includes aspect phrase; the unaccusative instances of the same verbs can only denote instantaneous events, since their structure lacks it. Finally, I assume that the path argument is basegenerated as an internal argument, and it moves to [Spec, aspect phrase] where it (i) specifies the duration of an event therefore receives the path interpretation (Tenny 1994) and (ii) is licensed by accusative case provided by $v$.

a. Gakusei-ga yama-o nobor -ta

student-NOM mountain-ACC climb -PERF

'Students climbed the mountain(s).'

b.

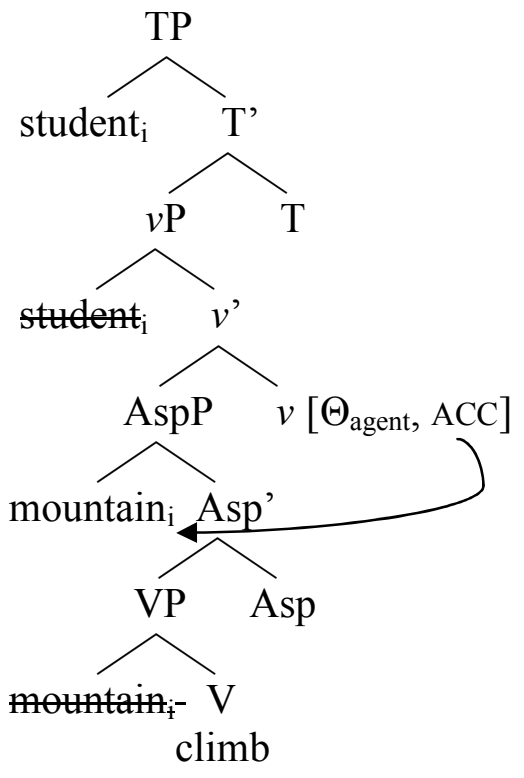




\section{Accusative-Dative Case Alternation in Japanese}

\section{Supporting Arguments}

In this last section, I provide supporting arguments for the proposed analysis. First I show that the proposed analysis correctly predicts that the unaccusative instances of the alternating verbs do not undergo causativization or passivization. I also argue that the proposed analysis accounts for some peculiarities of 'dative object' verbs, whose internal argument must be marked with dative case.

\subsection{Unaccusative-causative Alternation}

It has been noted in the literature that while many unaccusative verbs have their causative counterparts ('the butter melted.' vs. 'Bill melted the butter.'), not all of them do ('the package arrived.' vs. '*Bill arrived the package.')(Levin and Rappaport Hovav 1995 and references therein). In Japanese, many unaccusative verbs have morphologically related causative counterparts (ore 'break' vs. or 'cause to break'), but not all of them do (see Jacobson 1992 for an extensive list of the verbs that undergo the morphological alternations). Importantly, the alternating verbs under discussion do not have the causative counterparts.

There are two types of analyses available to account for the unaccusativecausative alternation. The alternation has been analyzed as causativization of unaccusative bases (i.e. Williams 1981, Brousseau and Ritter 1991, Hale and Keyser 2002) or decausativization of causative bases (i.e. Levin and Rappaport Hovav 1995, Reinhart 2002). ${ }^{3}$ Under the proposed analysis, unavailability of the causative forms of the alternating verbs has a simple account, if we adopt the causativization analysis of the alternation. Assuming that the causer external argument is introduced by a kind of $v$ (i.e. $v_{\text {cause }}$ in Folli and Harley 2005), the causer external argument cannot be added to the unaccusative structure because the position of $v$ is already occupied (17b). On the other hand, unaccusative verbs that undergo the unaccusative-causative alternation can be assumed to consist of a simple VP. Thus, the causer can be added with the appropriate $v$.

\subsection{Passivization}

The alternating verbs resist passivization when the subject of the active counterpart is only compatible with dative case (i.e. inanimate).

$$
\begin{aligned}
& \text { a. *Yuka-ga sukaato-ni/niyotte sawar -are -ta } \\
& \text { floor-NOM skirt-BY/BY touch -PASS -PER }
\end{aligned}
$$

'The floor was touched by the skirt.' (cf. (5))

$\begin{array}{lllll}\text { b. } & \text { Kabin-ga } & \text { kodomo-tachi-ni/niyotte } & \begin{array}{l}\text { sawar } \\ \text { vase-NOM }\end{array} & \text {-are } \\ \text { child-PL-BY/BY } & \text { touch } & \text {-PASS } & \text {-PER }\end{array}$

'The vase was touched by the children.'

\footnotetext{
${ }^{3}$ See Alexiadou et al (2005) for an approach that is different from the two approaches discussed here.
} 
Shin Fukuda

The proposed analysis offers an account for the badness of (19a). Assuming that passive sentences involve the $v$ head lacking accusative case (Krazter 1994, 1996), passivization of the unergative structure is unproblematic, since it simply promotes the path argument to be the subject where it is case-licensed with nominative case (20a). In contrast, passivization of the unaccusative structure would promote the goal argument to be the subject while leaving the theme argument case-less in situ (20b), causing the ungrammaticality.
a. $\quad\left[\mathrm{TP}\right.$ Path $\left[{ }_{\mathrm{vP}} \quad[\mathrm{VP}\right.$
Path V]
PASS]] (unergative)
b. *[тр Goal $\left[{ }_{\nu \mathrm{P}}[\mathrm{vp}\right.$ Goal Theme V]
PASS]] (unaccusative)

\subsection{Dative Object Verbs}

There are Japanese verbs which require their internal argument to be marked with dative case, such as aw 'meet', butsukar 'run into', and dekuwas 'come across'.

$$
\begin{array}{lll}
\text { Keiko-ga } & \text { Takeshi-ni/*o aw/butsukar/dekuwas } & \text {-ta } \\
\text { K-NOM } & \text { T-DAT/*ACC meet/run.into/come.across } & \text {-PERF } \\
\text { 'Keiko met/ran into/came across Takeshi.' } &
\end{array}
$$

These 'dative object verbs' share characteristics that are not shared by the verbs that take an accusative object, which, to my knowledge, have not received any account. First, these verbs never passivize (22a). Second, they always denote instantaneous events (22b).

$$
\begin{aligned}
& \text { a. *Ken-ga (Keiko-ni) aw/bustukar/dekuwas -are -ta } \\
& \text { K-NOM (K-BY) meet/run.into/come.across -PASS -PERF } \\
& \text { '*Ken was met/run_into/come_across by Keiko.' } \\
& \text { b. Ken-ga Taro-ni (*2-jikan) aw/bustukar/dekuwas -ta } \\
& \text { K- NOM T-DAT (*2-hour) meet/run.into/come.across -PERF } \\
& \text { 'Ken met/ran into/came across Taro (*for two hours).' }
\end{aligned}
$$

\begin{tabular}{|c|c|c|c|}
\hline $\begin{array}{l}\text { Kuruma }_{i} \text {-ga } \\
\text { cari-NOM }^{-}\end{array}$ & $\begin{array}{l}\text { ano-biru-ni } \\
\text { that-building-DAT }\end{array}$ & $\begin{array}{l}3-\mathrm{dai}_{i} \\
3-\mathrm{CL}_{\mathrm{I}}\end{array}$ & $\begin{array}{l}\text { butsukar } \\
\text { run.into }\end{array}$ \\
\hline
\end{tabular}

These behaviors of the dative object verbs can be accounted for, if we assume that these verbs have the same underlying structure as the proposed structure for the unaccusative instances of the alternating verbs. Under this assumption, the fact that they do not passivize can be accounted for in the same way in which the unaccusative instances of the alternating verbs cannot passivize. The fact that they are restricted to denote instantaneous events also follows from the presumed absence of aspect phrase. In fact, this analysis correctly predicts that subjects of the dative object verbs license a stranded numeral quantifier phrase: 


\section{Accusative-Dative Case Alternation in Japanese}

\section{Conclusion}

In this paper, I have argued that the Acc-Dat object case alternation attested with a small group of Japanese verbs is an instance of unergative/unaccusative alternation and proposed a syntactic analysis for it. According to the proposed analysis, the lexical entries of the alternating verbs only specify what arguments these verbs require, and it is the syntactic structure that decides (i) how the arguments are interpreted, (ii) how they are case-marked, and (iii) the event type of resulting sentences. I have also argued that the proposed analysis provides an account for the previously unanalyzed peculiar behaviors of a group of Japanese verbs that requires a dative object, or the dative object verbs. According to the proposed analysis, the dative object verbs are unaccusative verbs with two arguments, just like the unaccusative instances of the alternating verbs.

\section{References}

Alexiadou, Artemis, Elena Anagnostopoulou, and Florian Schäfer. 2005. The properties of anticausative crosslinguistically. In M. Frascarelli (ed.), Phases of Interpretation. 187-211. Berlin: Mouton de Gruyter.

Borer, Hagit. 1994. The projection of arguments. In E. Benedicto and J. Runner (eds.), Functional projections: University of Massachusetts Occasional Papers 17: 19-48.

Brousseau, Ann-Marie, and Elizabeth Ritter. 1991. A non-unified analysis of agentive verbs. WCCFL 10: 53-65.

Chomsky, Noam. 1995. The Minimalist Program. Cambridge, Mass: MIT Press.

Dixon, R.M.W. 1994. Ergativity. Cambridge, Cambridge University Press.

Folli, Raffaella, and Heidi Harley. 2005. Flavors of $v$ : consuming results in Italian and English, In P. Kempchinsky and R. Slabakova (eds.), Aspectual Inquiries. 95-120. Springer: Dordrecht.

Grewendorf, Günther. 1989. Ergativity in German. Dordrecht: Foris.

Hale, Ken, and Samuel Keyser. 2002. Prolegomenon to a Theory of Argument Structure. Cambridge, Mass: MIT Press

Hoekstra, Teun, and René Mulder. 1990. Unergatives as copular verbs: locational and existential predication. The Linguistics Review 7: 1-79.

Jacobson, Wesley M. 1992. The Transitive Structure of Events in Japanese. Tokyo: Kuroshio.

Jacobson, Wesley M. 1997. Agentivity and aspect in Japanese. In A. Kamio (ed.), Directions in Functional Linguistics. 83-116. John Benjamins.

Kageyama, Taro. 1993. Bumpo to gokeisei [Grammar and word formation]. Tokyo: Hitsuji shoboo.

Kindaichi, Kyosuke. 1976. Nihongo Dooshi no Asupekuto [Aspect of Japanese Verbs]. Tokyo: Mugi shobo.

Kratzer, Angelika. 1994. On external arguments. In E. Benedicto and J. Runner (eds.), Functional Projections: University of Massachusetts Occasional 
Shin Fukuda

Papers 17, 103-130.

Kratzer, Angelika. 1996. Severing the external argument from the verb. In J.

Rooryck and L. Zariing (eds.), Phrase Structure and the Lexicon. 109-137.

Dordrecht: Kluwer.

Kuno, Susumu. 1973. The Structure of Japanese. Cambridge, Mass. MIT Press.

Levin, Beth, and Malka Rappaport-Hovav. 1989. An approach to unaccusative mismatches. NELS 19: 314-328.

Levin, Beth, and Malka. Rappaport-Hovav. 1995. Unaccusativity: at the SyntaxLexical Semantics Interface. Cambridge, Mass: MIT Press.

Miyagawa, Shigeru. 1989. Light verbs and the eargative hypothesis. Linguistics Inquiry 20. 659-668.

Perlmutter, David. M. 1978. Impersonal passives and the unaccusative hypothesis. BLS 4. 157-189.

Reinhart, Tanya. 2002. The theta-system - an overview. Theoretical Linguistics 28: 229-290.

Rosen, Carol. G. 1984. The interface between semantic roles and initial Grammatical relations. In D. Perlmutter and C.G. Rosen (eds.), Studies in Relational Grammar 2. 38-80. Chicago: The University of Chicago Press.

Sadakane, Kumi, and Masatoshi Koizumi. 1995. On the nature of the "dative" particle $n i$ in Japanese. Linguistics 33: 5-33.

Sugamoto, Nobuko. 1982. Transitivity and objecthood in Japanese. In P. J.

Hopper and S. A. Thompson (eds.) Syntax and Semantics 15: Studies in Transitivity. 423-447. New York: Academic Press.

Tenny, Carol. L. 1994. Aspectual roles and the syntax-semantics interface. Dordrecht: Kluwer.

Tsujimura, Natsuko. 1994. Unaccusative mismatches and resultatives in Japanese. In M. Koizumi and H. Ura (eds.), Formal Approaches to Japanese Linguistics 1. MIT Working Papers in Linguistics 24: 335-354.

Travis, Lisa M. 1991. Derived object, inner aspect, and structure of VP. Paper presented at NESL 22.

van Valin, Robert. D. 1990. Semantic parameters of split intransitivity. Language 66: 221-260.

Williams, Edwin. 1981. Argument structure and morphology. The Linguistic Review 1: 81-114.

Zavala, Roberto. 2007. Split intransitives and agentivity in Cholan and other Mayan languages. Paper presented at BLS 33.

Shin Fukuda

Department of Linguistics

University of California, San Diego

9500 Gilman Dr.

La Jolla, CA, 92093-0108

fukuda@ling.ucsd.edu 